\title{
Effect of Auditing on Financial Performance of Water and Sanitation Company in Kirinyaga County, Kenya
}

\author{
Lucy Wangithi Munene ${ }^{1}$, Mungai John Njangiru ${ }^{1}$, Susan Wahito Ngungu ${ }^{2}$ \\ ${ }^{1}$ Department of Accounting and Finance, Kenyatta University, Nairobi, Kenya \\ ${ }^{2}$ Department of Business and Economics, Maasai Mara University, Nairobi, Kenya
}

Email address:

lucy.munene@yahoo.com (L. W. Munene),njangiru07@gmail.com (M. J. Njangiru),ndungususan22@yahoo.com (S. W. Ndungu)

To cite this article:

Lucy Wangithi Munene, Mungai John Njangiru, Susan Wahito Ngungu. Effect of Auditing on Financial Performance of Water and Sanitation Company in Kirinyaga County, Kenya. Journal of Finance and Accounting. Vol. 4, No. 5, 2016, pp. 271-284. doi: 10.11648/j.jfa.20160405.14

Received: July 6, 2016; Accepted: July 26, 2016; Published: September 7, 2016

\begin{abstract}
Within the framework of modern business world, auditing is a major part of managing an organization. Audits are performed to ascertain the validity and reliability of information and also to provide an assessment of a system's internal control. The goal of an audit is to express an opinion on the truth and fairness of the organization financial statements. The theories guiding this research are the policeman theory, the lending credibility theory and the theory of inspired confidence and the agency theory. The overall objective of this study was to examine the effect of auditing on financial performance of Water and Sanitation Company in Kirinyaga County. The specific objective was to determine the influence of auditor's independence on financial performance of Water and Sanitation Company in Kirinyaga County. The study used a descriptive survey research design targeting the top management level, middle management level and lower management level staffs of Kirinyaga Water and Sanitation Company. A sample of 42 respondents was selected from a study population of 137 staffs of the company. Proportionate stratified random sampling method was used to get the sample size. Data was collected from primary sources i.e. directly from respondents through open and close ended questionnaires. The collected data was both qualitative and quantitative. The qualitative data was analyzed using content analysis while quantitative data was analyzed using multiple regression analysis and correlation analysis. Analyzed data was then presented in form of data tables. The results of the study revealed that there is a positive relationship between financial performance success and auditor's independence. The study therefore recommends that Kirinyaga Water and Sanitation Company should maintain and enhance audit assurance services and strong internal control environment.
\end{abstract}

Keywords: Auditors Independence, Corporate Governance, Audit Committee, Internal Audit, External Audit

\section{Introduction}

\subsection{Background of the Study}

The word audit is derived from the Latin word audile, which means to hear. Thus in the beginning, the word audit was meant to hear and auditor literally meant a hearer (Salehi, 2008). External auditors are authorized by law to examine and publicly issue an opinion on the status and reliability of company's financial reports. The main objective of the financial statement audit is to add credibility to management's financial statements hence allowing owners, investors, bankers, and other creditors to use them with greater confidence. However an audit does not guarantee financial statements accuracy. It provides users with a reasonable assurance that the firm financial statements give a true and fair view about its financial position and its operations.

One of the core activities of auditing is to obtain and evaluate documentary and other types of evidence. Public auditors should reduce agency problems and improve transparency in all operations in an organisation. Auditing is a regulated function, but it is also based on the professional judgement of the auditors (Eklov, 2001). Auditors are expected to rely on their experience and bring many aspects into consideration before issuing their reports. Auditing increase the confidence of the users of the financial information like investors, owners, creditors and any other users who may have an interest with the financial position of an organization.

Auditing evolved to cater the needs of different users, for 
instance it provides unbiased facts regarding actual or potential risks, and effectiveness and inefficiencies of systems and processes for the decision making of management (Russell, 2005). External auditors are supposed to apply professionalism when they are carrying out their duties and should work according to guidelines to avoid issue of bias report. If they do not work according to guidelines or they issue a wrong report, it may give a bad outlook of the audit profession. Auditors are suppose to work for the best of their clients and investors otherwise are subject to lawsuits from investors and face legal liability for overstatement. The audit opinion provided by the auditors over the financial reports of a client-firm is regarded of much value in terms of the success of an audit in reducing the risk of material misstatements, and enhancing the quality and credibility over the financial reports.

External auditing which is the function of statutory auditors is the process of reviewing the accounting and financial books of a company by a certified public accounting firms (Inyiama, 2010). External auditing is conducted by an individual or firm that is independent of the company being audited. The books of accounts of the company are mostly audited once per year after completion of the financial year. Their role is to give an opinion on the financial statements of their clients. Based on their findings during the audit exercise, they also produce a management letter which acts as an advice to the management of the company. This helps the management on how to improve their organization and working methods to enhance achievement of the organizations goals and objectives.

The auditor is supposed to review and evaluates internal control systems maintained by the organization, which if strong helps to prevent material mis-statements of the financial statements. Professional auditors are less willing to accept questionable financial documents and are more likely to report errors and irregularities revealed during the audit exercise. Gray \& Manson (2008) asserts that, an audit is an investigation or search for evidence to enable an opinion to be formed on truth and fairness of financial and other information by a person or persons independent of the preparer and persons likely to gain directly from the use of the information, and the issue of a report on that information with the intention of increasing its credibility and therefore its usefulness.

Elder, Beasley and Arens (2006) indicates that, the demand for audit services is triggered by many factors including the remoteness gap between the users of the financial statements and the preparers of these statements, the conflict of interest between the users of the financial statements, the complexity of the economic transactions and the expected effect of the financial statements on decision making. Auditing is important to avoid the potential conflict of interest between the managers and the stakeholders. The audit report is the medium of communication between the auditor and the users. Therefore the report must be understandable, objective and accepted by the users as a relevant source of information. It must be relevance in the essence that it does not mislead the users during decision making process on financial matters.

Professionally, internal auditors strive to create an effective function whose results can be relied upon by the external auditors as evidence of the overall strength of internal financial control. The detailed background knowledge which internal audit has of the organization may be of particular value in allowing their external counterparts to understand the background and circumstances of the activity they are reviewing. Establishing a professional working relationship between the internal auditor and the external auditor should deliver benefits to both parties. However, such cooperation can only thrive in an environment where there is mutual confidence and there cognition that internal and external audits are both conducted within relevant professional standards and information exchanged is treated professionally and with integrity (NAO, 2000)

\section{Auditing in Kirinyaga Water and Sanitation Company}

Kirinyaga Water and Sanitation Company (KIRIWASCO) is a registered company limited by guarantee and contracted by Tana Water Services Board (TSWB) to run the following supply schemes; Ndia, Kerugoya, Sagana and Wanguru. The Company covers an area of about $1000 \mathrm{Km}^{2}$ which has a population of about 445,000 and about 150 staff. Its head office is in Kerugoya Town, Kirinyaga Central District, Kirinyaga County. The Board of Director is responsible for strategic direction, policy making, co-ordination and control of Company functions (KIRIWASCO, 2014)

The management team implements strategies and plans approved by the BOD and carries out the daily running of the business. KIRIWASCO is mandated to provide water and sanitation services efficiently and economically within its area of jurisdiction as authorized through the Water Services Provision Agreement (SPA) and as mandated by Section 55 of the Water Act 2002. The water services provided includes, extension of water supply, connections to water supply, billing and bill distribution, payment for services, disconnection, reconnection and operation and maintenance (KIRIWASCO, 2014).

Auditing in KIRIWASCO is carried out through competitive bidding. Advertisement of audit services is communicated through daily newspapers and the company's website. Interested consultants are advised to express their interest for provision of consultancy services for external audit by purchasing the tender documents during official working hours at a certain non refundable fee. An external auditing function is seen as a powerful tool in KIRIWASCO that can aid the company's performance in corporate governance. The external auditors conduct annual auditing on the company's financial statements to abide to government regulations. The Companies Act Cap 486 requires the BOD to prepare financial statements for each year that give a true and fair view of the state of affairs of the company as at the end of the financial year and of the results of the activities for that year. It is the responsibility of the external auditor to express an opinion on these financial statements based on the audit and report in accordance with the provisions of Section 15 (2) of the Public Audit Act, 2003 and submit the audit report (KIRIWASCO, 2014).

The audit is conducted in accordance with International 
Standards of Auditing (IAS). These standards require compliance with ethical requirements and that the audit be planned and performed to obtain reasonable assurance about whether the financial statements are free from material misstatements. The external auditor is required to obtain all the information and explanations which, to the best of his knowledge and belief are necessary for the purpose of the audit. The company has also established the internal auditing department which implements and ensures the internal control systems are strong and maintained within the organizations operations. The audit exercise also includes evaluating the appropriateness of accounting policies used and the reasonableness of accounting estimates made by the management, as well as evaluating the overall presentation of the financial statements (KIRIWASCO, 2014).

\subsection{Statement of the Problem}

Over the last decade, successive governments in Kenya have been undertaking reforms in the water sector, a principal objective of which has been to enhance private sector participation in water provision. In the context of these reforms, a new Water Act was enacted in 2002, which transformed the institutional framework for water governance. The sector has thus undergone major structural reforms aimed at improving service provision. However, water services studies done within the sector reveal that, the management of water resources and water supply has continued to be a major problem. Ombogo (2006) assert that, the sector lacks the resources and capacities required to adequately carry out water sector reforms.

Kirinyaga Water and Sanitation Company (KIRIWASCO) is one of the Water Service providers (WAPs) in Kenya that have been involved in allegations of poor management and corruption in its operations. It took the interception of Tana Water Services Board (TWSB) to appoint a new administrator to take over the company management on acting capacity until auditors completed their investigations (www.kirinyagawaterandsanitation.com). This is an indication of underlying problem in Kirinyaga County. In short, water supply in urban Kenya is still characterized by low coverage, unreliable service, poor financial management and neglected operation and maintenance. This has translated into generally inadequate services which are particularly lacking for the urban poor (WASP, 2005).

Audit is a key contributor to financial stability and re-establishment of trust and market confidence. Auditors are entrusted by law with conducting statutory audits and fulfill an important role in offering an opinion on whether the financial statements are stated truly and fairly (Quick, 2012). This assurance should therefore reduce the risk of misstatement hence subsequent reduction of the costs of business failures. The value of auditing is both internal and external. To the auditee, audit assurance decreases the risk of internal controls, misstatement, hence decreasing the possibility of business failure. For the information of users outside the organization, the assurance will reduce the risk of information asymmetry, optimize the allocation of resources which in return gives confidence to stakeholders while making financial decision. In modern times the need and role of auditing has gone to mere certification that the financial statements are in respect to their truth and fairness. An assurance that fraud and other irregularities perpetuated in organization may not go without detection is also a requirement.

The objective of audit has been identified to be two folds namely primary and secondary objectives (Adeniji, 2004). The primary objective is for the appointed auditor to write a report expressing his professional opinion on the truth and fairness of the financial statements examined so as to give confidence to those parties who may want to make decisions based on them. The secondary objectives include to detect and prevent errors and fraud and to provide other services to the client in areas such as accounting work, financial analysis, and tax matters among others.

The need for auditing of financial statements evolved basically as a result of the growing complexity in business. The separation of ownership from management particularly created a need for verification and authentication of results of operations presented in financial statements produced by management who were entrusted with resources by a third party independent of management itself to express an opinion on their truth and fair state (Gupta, 2005). Furthermore, Lin and Liu (2009) added that an effective auditing function can detect and disclose earnings management and other types of misconduct by business managers or controlling shareholders.

\subsection{Objectives of the Study}

\subsubsection{General Objective}

The general objective of the study was to examine the effect of auditing on financial performance of Water and Sanitation Company in Kirinyaga County.

\subsubsection{Specific Objective}

i. To determine the influence of auditors independence on financial performance of Water and Sanitation Company in Kirinyaga County.

\subsection{Research Question}

i. What influence does auditor's independence have on financial performance of Water and Sanitation Company in Kirinyaga County.

\subsection{Significance of the Study}

The trustworthiness of auditing and financial reports has become a headline for financial news papers, media and internet forums. Reliability on auditor's work is the most crucial factor that is demanded by the investors around the globe to make their decisions about future spending. Therefore the results of the study will help identify gaps within the auditing exercise in Water and Sanitation Companies in Kenya.

It is also the researcher's belief that invaluable benefits to management of KIRIWASCO and those charged with governance in Water and Sanitation Companies in Kenya will 
emerge on how to streamline auditing exercise thus ensuring improved financial performance and ultimately ensure attainment of the organizations objectives.

In addition, a culture of accountability leading to profitability would be inculcated over time, leading to greater impact and realization of visions as set out in their goals and objectives. The government may also use the findings together with others from similar studies to enlist the support of the Water and Sanitation Companies in carrying out interventions in providing quality services to the community and the TWSB in formulating its policies for the success of the water sector reforms. Finally, the Academia will benefit by having a reference point in future research as this research adds to the existing auditing literature, also potential areas for further research on matters related to auditing in the Water and Sanitation companies will be pointed out.

\subsection{Scope of the Study}

The target population for this study comprised of the top level management, middle level management and lower level management of the staff in Kirinyaga Water and Sanitation Company (KIRIWASCO). The respondents included the top management, middle level management and lower cadre. The study only dealt with aspects of corporate governance, auditors' independence, internal audit function and the audit Committee.

The study relied on primary data to make analysis and conclusions which were collected through the use of open and closed ended questionnaires. The study took a time frame of seven months, from October 2014 to April 2015. Choice of this location was based on the fact that KIRIWASCO is among the Water and Sanitation Company that had experienced the challenges facing the implementation of water sector reforms and interventions in Kenya.

\subsection{Limitation of the Study}

The researcher faced challenges such as a negative attitude by the respondents who felt that by giving information in the questionnaire the organization would be exposed in a negative way. The researcher handled the problem by using an introduction letter from the University and assured them that the information they gave would be treated confidentially and it would be used purely for academic purposes.

In addition, the study also faced with a problem of not finding all respondents in the time of the study due to them being too busy with the organization work. The researcher however had to draft the appropriate time table with the top company managers that may suit all the respondents during the process of data collection for reliable and valid information.

\section{Literature Review}

This chapter contains theoretical literature review and empirical review. Literature of the previous studies will be covered quoting important contributors to the issues related to the study.

\subsection{Theoretical Literature}

An independent external auditor ensures that the financial statements are credible to be relied upon by stakeholders like trade creditors, bankers, stockholders, government and other interested third parties in decision making process. Audited financial statements are now in the current business environment the established means by which organizations can state their operating results and financial position. Hayes, Dassen, Schilder \& Wallace (2005) identified four theories of auditing which explain the existence of auditing namely; Policeman theory, lending credibility theory, inspired confidence theory and agency theory.

\subsubsection{The Policeman Theory}

Under this theory, an auditor acts as a policeman focusing on arithmetical accuracy and on prevention and detection of fraud. This theory makes the auditor to detect and prevent errors and fraud in organizations. The management should establish and maintain strong internal control systems to enhance prevention and detection of fraud and any other irregularities within the organization. It is not the responsibility of the auditor to look for fraud unless he enters into a specific agreement with the management to do so. However, if audit is properly carried out the work of auditor should expose fraud and irregularities where they exist. The main focus of auditors is verification of the truth and fairness of the financial statements and provision of reasonable assurance. The detection of fraud is however still a hot topic in the debate on the auditor's responsibilities and typically after events where financial statement frauds have been revealed, the pressure increases on increasing the responsibilities of auditors in detecting fraud (Hayes et al, 2005).

\subsubsection{The Lending Credibility Theory}

This theory suggests that the primary function of the audit is to add credibility to the financial statements. The user's confidence is increased upon relying on audited financial statements rather than the financial statements presented by the management. The management therefore uses the audited financial statements to enhance stakeholder's faith in their managerial performance. The users are perceived to gain benefits from the increased credibility, these benefits are typically considered to be that, the quality of investment decisions improve when they are based on reliable information (Hayes et al. 2005). The audited financial statements enhance principal agent's relationship and reduce information asymmetry. Akinbuli (2010) states that audited financial statements can enhance stakeholders' faith in management's stewardship.

\subsection{Empirical Literature}

The performance of business corporations which is the operating results and financial positions can only be communicated through audited financial statements. Reduction of frauds, objective reporting, transparency and disclosure, strong internal control, accountability, external audit and other policies has enhanced the management of a 
company to improve their efficiencies in their operations. Decision makers use the audited information on the assumption that it is reasonably complete, accurate and unbiased.

\section{Auditor Independence and Financial Performance}

Audit independence refers to the ability of the external auditor to act with integrity and impartiality during auditing process. The independent auditor plays a very crucial role in ensuring that financial statements faithfully represent the activities of management during the period covered by the financial report (Otalor, 2012). The independence of the auditor is one of the most important factors to consider since it increases the effectiveness of the audit process by ensuring objectivity is adhered. Auditor independence helps to ensure quality audits and reliance on financial statement by users. This can be sustained if the auditor has no management connections since he will appear as if he is involved in management decisions.

The impairment or lack of external auditor independence is a main cause of many corporate collapses and corporate scandals across the world. Communication on accuracy of the financial statements is very vital to management, owners and other users because they depend on this information to make financial decisions. The independency of external auditor will increase the confidence of company's financial statements by expressing an opinion on the fairness of the statements. Louwers, Ramsay, Sinason, and Strawser (2007) express independence as a mental attitude and physical appearance which portrays the auditor as being uninfluenced by others in judgment and decision.

Audit tenure refers to the number of years audit firms or engagement partners have spent on the audit of a particular client. At times long auditor's tenure may lead to a close connection or relationship between the client and the auditor. This may impair the auditor's independence due to a decrease in the auditors due diligence and also failure to comment on inappropriate managerial actions for the sake of maintaining the relationship. Klimentchenko (2009) was of the opinion that if an auditor or a representative of the audit firm reviews the financial information of a client, year-after-year, he becomes familiar with the business of his client, develops a desire to maintain good rapport with the manager of the client's business and thereby losing his impartiality.

Long audit tenure may also results to over familiarity resulting to decline of the quality and competence of the auditors work by making unjustified assumptions instead of objective evaluation of evidence laid by the management. This means that the independent action by the auditing firm becomes difficult. On the other hand, long auditor tenure is beneficial as auditors gain expertise in the field they audit and may reduce the auditor's ability to detect irregularities or material misstatements (Gul, Jaggi \& Krishnan, 2009).

The size of audit firm is an essential characteristic that reflects auditor independence. Auditor reputation is directly associated with audit quality. Large audit firms ensures they provide an independent quality audit service since they have better research facilities, efficient financial resources, more advanced technology and more skilled employees who will be able to undertake large company audits as compared to smaller audit firms. Muhammad and Karbhari (2006) opined that, big audit firms are better able to resist management pressure in conflict situations than smaller audit firms. At times, smaller firms may have a more personal and close relationship with their clients.

The public generally perceive large audit firms as provider of high audit quality and enjoy a high reputation in the business environment. Large audit firms would therefore strive to maintain their independence to keep up their image to maintain their clients. It has been argued that larger auditees, due to the complexity of their operations and the increase in the separation between management and ownership, demand highly independent audit firms to reduce agency costs and auditors self-interest threat (Hudaib, 2003). The auditor's size should therefore be measured on the basis of the company assets, market share and the number of employees in the organization.

Competition in the audit market is one of the factors that have been identified as undermining auditor independence. It is one of the most important environmental change or external factor affecting the independence of an auditor. Where an auditing firm is operating in an intensely competitive environment, it may have difficult to remain independent since the client can obtain the same services from another auditor or competitor. Gul (2005) argued that, the existence of competition causes auditors to be more independent and create a favorable image in order to maintain their clientele. Auditors should perform their duties to reduce audit risk to an acceptable level regardless of the competitive environment they are working in.

Non-audit services (NAS) may be any services other than audit provided to an audit client by an incumbent auditor. They are professional services provided by the auditor during the period of an audit engagement which are not connected to an audit for instance, bookkeeping, tax services, strategic planning, human resource planning, computer hardware and software installation and implementation and internal audit outsourcing. Knechel and Sharma (2008) argue that auditor providing non-audit services have been a controversial topic in the auditing profession for many years and are one of the key issues in debates between regulators and the accounting profession regarding potential threats to auditor's independence.

When audit and NAS are provided to the same client the auditor must ensure that he does not jeopardize his independence because there are occasions where independence may be threatened by the provision of services other than audit. Even though joint-provision could be beneficial in terms of cost saving, the possible effect on the impairment of auditor's independence is a concern since he provides consultancy services to management at the same time undertakes an audit on behalf of the shareholders. As such Hay et al, (2006) suggests that there exists a potential for the impairment of auditor independence in appearance when they render non-audit services. 


\subsection{Financial Performance}

Financial performance is a subjective measure of the accountability of an entity for the results of its policies, operations and activities quantified for an identified period in financial terms. In the public sector the nature of financial performance is a function of what the public sector entity is held accountable for accomplishing in financial terms in the identified period (Adams, 2003). This term is also used as a general measure of a firm's overall financial health over a given period of time, and can be used to compare similar firms across the same industry or to compare industries or sectors in aggregation.

\subsubsection{Profit Realized}

Profitability can be defined as the final measure of economic success achieved by a company in relation to the capital invested in it. This economic success is determined by the magnitude of the net profit accounting (Pimentel, Braga \& Casa, 2005). Profitability is measured by different ratios such as, Return on Equity (ROE), Price to Earnings Ratio (PER) and Return on Assets (ROA) amongst others. The measurement of profitability is essential to every company (Eljelly, 2004). Profitability is measured with income and expenses. Income is money generated from the activities of the business. However, money coming into the business from activities like borrowing money does not create income. This is simply a cash transaction between the business and the lender to generate cash for operating the business or buying assets. Expenses are the cost of resources used up or consumed by the activities of the business.

\subsubsection{Satisfied Employees}

Employee satisfaction is a measure of how happy workers are with their job and working environment. It is sure that there may be many factors affecting the organizational effectiveness and one of them is the employee satisfaction. Effective organizations should have a culture that encourages the employee satisfaction, Bhatti \& Qureshi, (2007). Employees should be satisfied with competitive salary packages and they should be satisfied with it when comparing their pay packets with those of the outsiders who are working in the same industry. A feeling of satisfaction is felt by attaining fair and equitable rewards. So, every organization should develop strategies that strengthen the work environment and increase the employee morale and employee satisfaction to enhance employee performance and productivity, which ultimately results in high profits, customer satisfaction as well as customer retention.

\subsection{Research Gaps}

Table 1. Knowledge Gap.

\begin{tabular}{|c|c|c|c|c|}
\hline Studies by: & Focus & Findings & Knowledge Gap & Focus of proposed study \\
\hline $\begin{array}{l}\text { Klimentchenko } \\
(2009)\end{array}$ & $\begin{array}{l}\text { External auditor } \\
\text { independence in } \\
\text { relation to tenure } \\
\text { of audit }\end{array}$ & $\begin{array}{l}\text { External auditor independence } \\
\text { is impaired if he becomes } \\
\text { familiar with the clients } \\
\text { business year after year }\end{array}$ & $\begin{array}{l}\text { Study did not look into the external } \\
\text { auditor independence and } \\
\text { organizational policies that may affect } \\
\text { realization of its goals and objectives }\end{array}$ & $\begin{array}{l}\text { Current study to focus on corporate } \\
\text { governance, auditors independence, } \\
\text { internal audit function and audit } \\
\text { Committee }\end{array}$ \\
\hline
\end{tabular}

Source: Author (2014)

\subsection{Conceptual Framework}

The relationship between the various variables on effect of audit on financial performance is depicted as shown below:

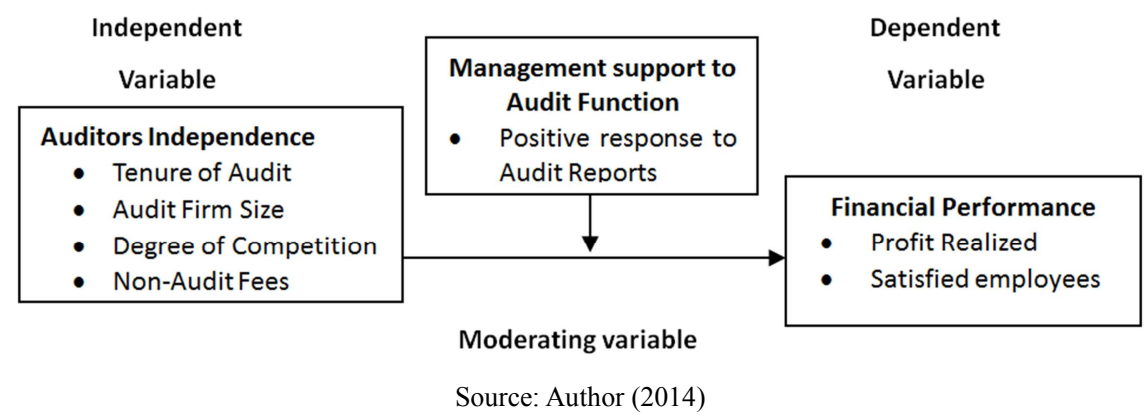

Fig. 1. Conceptual Frame work.

\section{Research Methodology}

Research methodology is the plan which enables collection and analysis of data in the most economical and feasible manner. This chapter explains the research design, sampling technique, data collection, analysis and interpretation methods that will be used in carrying out this study.

\subsection{Research Design}

The researcher used a descriptive survey research design to carry out the research. Oso and Onen (2008) assert that, descriptive survey design presents an oriented methodology used to investigate population by selecting samples to analyze and discover occurrences. It is a method used to narrow down 
a very broad field of research into one easily researchable topic. A descriptive survey design may focus on opinions or factual information depending on its purpose, but all surveys involve administering questions to individuals (Kombo \& Tromp, 2006).

Descriptive survey research design is relevant to this study because the study sought to establish the effect of audit on financial performance in Water and Sanitation Company in Kirinyaga County hence an efficient method for systematically collecting data from broad spectrum of individuals. Survey was also used because of its economy, rapid data collection and ability to understand a population from a part (Oso \& Onen, 2008).

\subsection{Target Population}

The target population for this study comprised of the top level management, middle level management and lower level management of the staffs in Kirinyaga Water and Sanitation Company. This ensured that every employee at each level with relevant information on auditing was sampled. The target population was provided by the management of the organization as indicated in the table below. Kombo, (2006) defines a population as a group of individuals, objects or items from which samples are taken for measurement.

Table 2. Target Population.

\begin{tabular}{ll}
\hline Management Levels & No. of Staffs \\
\hline Top Management & 4 \\
Middle Management & 37 \\
Lower Management & 96 \\
TOTAL & 137 \\
\hline
\end{tabular}

Source: KIRIWASCO, 2014

\subsection{Sampling Design}

Proportionate stratified random sampling method was used to select the sample population. The sample size of each stratum in this technique is proportionate to the population size of the stratum when viewed against the entire population. This means that the each stratum has the same sampling fraction. The sample size was arrived at by using $30 \%$ of the target population. According to Mugenda and Mugenda (2003), a sample ratio of 0.3 should be sufficient to obtain sample representation of each stratum of respondents from all the three levels of management as shown in Table 3 below. A sample size of 42 employees was used to carry out this study.

Table 3. Sample Population

\begin{tabular}{ll|l|l}
\hline Strata & Target Population & Percentage & Sample size \\
\hline Top Management & 4 & $30 \%$ & 1 \\
Middle Management & 37 & $30 \%$ & 12 \\
Lower Management & 96 & $30 \%$ & 29 \\
Total & 137 & & 42 \\
\hline
\end{tabular}

Source: Author (2014)

\subsection{Data Collection Instruments and Procedure}

Data collection is the gathering of information relevant to the research study. The data was collected from primary sources. Primary data was collected directly from the respondents. The researcher used questionnaires which consisted of both open and closed ended questions to collect data. The questionnaires were dropped to the respondents and picked later. Follow up was by personal calls to the respondents to ensure that the agreed duration was not extended.

Mugenda (2008) lays down the facts as to why the questionnaire is important. First, it helps the researcher to collect information from respondents in different places. While using the questionnaire as a method of data collecting, emotions and undue influence is avoided during the time of data collection. The questionnaire method ensures that confidentiality is maintained. This method is also cheap and saves time in data collection. According to Kothari (2004) use of questionnaire gives respondent adequate time to give well thought out answers.

\subsection{Validity and Reliability}

\subsubsection{Validity of the Research Instrument}

Validity is the accuracy and meaningfulness of inferences based on the research findings. It is a measure of how well a test measures what it is supposed to measure. It is concerned with the accurate representation of the variables under study. This was addressed in this study by good instrument design to reflect the research objectives and pre-testing the instruments (Borg \& Gall, 1997). Data completeness and uniformity was maintained and this facilitated application of other data analysis techniques like coding, data organization, data classification and tabulation. Content validity was used to confirm that the research instrument was appropriate to generate the desired response.

\subsubsection{Reliability of the Research Instrument}

Reliability is the measure of the consistency of the results from the tests of the instruments. It is a measure of the degree to which a research instrument yields consistent results or data after repeated trials. It is influenced by random error. Reliability of the research instrument was tested using Cronbach's alpha $(\alpha)$ coefficient of reliability. The Cronbach's alpha coefficient ranges from 0 to 1 . The higher the score, the more reliable the generated scale is. The reliability test for Auditor's independence was 0.704 . After ascertaining that the instrument was giving consistent results, it was adopted as the main tool used for data collection. According to Fraenkel and Wallen (2000), as a rule of thumb, a proposed psychometric instrument should only be used if an alpha value of 0.70 or higher is obtained on a substantial sample.

\subsection{Data Analysis and Data Presentation}

The data collected was both qualitative and quantitative. The qualitative data was analyzed using content analysis. Descriptive statistics was used to analyze quantitative data using frequency distributions as well as percentages while multiple regression analysis was used for inferences. Correlation analyses were used to measure the relationship 
between variables.

According to (Freedman, 2005) multiple regression analysis is useful for generalizing functional relationships between variables. The researcher used a multiple regression model to establish if the relationship between the independent variables and the dependent variables was statistically significant. Multiple regression analysis was used to ensure that all variables were in place for the change of dependent variable. A general regression model was adopted:

$$
Y=\alpha+\beta_{1} X_{1}+\beta_{2} X_{2}+\beta_{3} X_{3}+\beta_{4} X_{4}+\varepsilon
$$

Where $\mathrm{Y}=$ Financial Performance, $\mathrm{X}_{1}=$ Corporate Governance, $X_{2}=$ Auditors Independence, $X_{3}=$ Internal Audit

Function, $\mathrm{X}_{4}=$ Audit Committee and $\varepsilon=$ Error term

The regression coefficient ' $a$ ' is the $Y$ intercept: while $\beta_{1}, \beta_{2}$, $\beta_{3}$ and $\beta_{4}$ are the net change in $y$ for each change of $X_{1}, X_{2}, X_{3}$ and $X_{4}$. The error term is a random variable with a mean of zero, which captures those variables that cannot be quantified. The finding of the study was then presented, analyzed and interpreted using tables.

\subsection{Ethical Issues}

The researcher first sought consent from the management of the company to carry out the study. The management and the respondents were given the understanding that the findings would be used to improve or strengthen the existing external auditing practice and add to the body of knowledge for further research by academicians. The identity of respondents giving information was made private and confidential to prevent any victimization.

\section{Research Findings and Discussions}

This chapter discusses the interpretation and presentation of the findings obtained from the field. Descriptive and inferential statistics have been used to discuss the findings. The findings are presented and analyzed according to the research objectives. Brief explanations have been given to help the reader to understand what the results mean.

\subsection{Response Rate}

Table 4. Response rate.

\begin{tabular}{llll}
\hline \multicolumn{2}{l}{ Levels of Management } & Frequency & Percent \\
\hline \multirow{4}{*}{ Valid } & Top Management & 1 & 2.5 \\
& Middle Management & 12 & 30.0 \\
& Lower Management & 27 & 67.5 \\
& Total & 40 & 100.0 \\
\hline
\end{tabular}

Source: Survey data, 2015

A total of 42 questionnaires were distributed to the employees of KIRIWASCO out of which 40 were received back making a response rate of $95.2 \%$. Social response rates vary and there exist various expert opinions as to what is considered a good response rate. Kiess and Bloomquist (1985) cited $60 \%$ as a good response rate whereas Bailey (1987) cited $75 \%$ as acceptable response rate. This was also acceptable according to Mugenda and Mugenda (2003). The response rate shown in table 4 above is therefore considered acceptable.

\subsection{Preliminary Bio-data Analysis}

Descriptive statistics were used to summarize and describe the general demographic profile of the respondents that had been collected using part A of the research questionnaire.

\subsubsection{Gender}

Table 5. Distribution of Respondents in terms of Gender.

\begin{tabular}{lllll}
\hline Gender & & Frequency & Percent & Cumulative Percent \\
\hline \multirow{4}{*}{ Valid } & Female & 18 & 45.0 & 45.0 \\
& Male & 22 & 55.0 & 100.0 \\
& Total & 40 & 100.0 & \\
\hline
\end{tabular}

Source: Survey data, 2015

The researcher sought to establish the ratio of male employees to female employees which is depicted by the table 5 above. The sample size was 42 employees of KIRIWASCO of which the returned response was 40 . Table 5 above shows that majority of the respondents (55\%) were males while $45 \%$ were females. This is a clear indication that there exists a gender imbalance in the staff at KIRIWASCO.

\subsubsection{Marital Status}

Table 6. Distribution of Respondents in terms of Marital Status.

\begin{tabular}{clll}
\hline Marital Status & Frequency & Percent & Cumulative Percent \\
\hline Single & 10 & 25.0 & 25.0 \\
Married & 24 & 60.0 & 85.0 \\
Valid Widow/Widower & 5 & 12.5 & 97.5 \\
Separated & 1 & 2.5 & 100.0 \\
Total & 40 & 100.0 & \\
\hline
\end{tabular}

Source: Survey data, 2015

The sample size was 42 employees of KIRIWASCO of which the returned response was 40 . Table 6 above reveals that majority of respondents $(60 \%)$ are married followed by single $(25 \%)$, followed by widowed $(12.5 \%)$ and separated at $2.5 \%$ respectively. This implies that majority of respondents embrace the family values.

\subsubsection{Age Distribution}

Respondents were asked questions related to their age so as to establish the productivity of the population sample. The sample size was 42 employees of KIRIWASCO of which the returned response was 40 and the results are shown in the table below:

Table 7. Distribution of Respondents in terms of Age.

\begin{tabular}{lllll}
\hline \multicolumn{1}{l}{ Age group } & Frequency & Percent & Cumulative Percent \\
\hline \multirow{4}{*}{ Valid } & $18-30$ & 13 & 32.5 & 32.5 \\
& $31-40$ & 18 & 45.0 & 77.5 \\
& $41-50$ & 8 & 20.0 & 97.5 \\
& $51-60$ & 1 & 2.5 & 100.0 \\
& Total & 40 & 100.0 & \\
\hline
\end{tabular}

Source: Survey data, 2015 
From Table 7 above it is evident that the majority of the respondents (45\%) are in the age bracket of between 31-40 years. This implies that KIRIWASCO has a productive human capital.

\subsubsection{Level of Education}

The researcher sought to find out the kind of people employed by KIRIWASCO. The sample size was 42 employees of KIRIWASCO of which the returned response was 40 .

Table 8. Distribution of Respondents in terms Level of Education.

\begin{tabular}{llll}
\hline Level of Education & Frequency & Percent & Cumulative Percent \\
\hline Secondary School & 3 & 7.5 & 7.5 \\
Middle level College & 21 & 52.5 & 60.0 \\
Valid University & 10 & 25.0 & 85.0 \\
Post-University & 5 & 12.5 & 97.5 \\
Others & 1 & 2.5 & 100.0 \\
Total & 40 & 100.0 & \\
\hline
\end{tabular}

Source: Survey data, 2015

On the highest level of academic qualification reached by the respondents, the findings revealed that $52.5 \%$ of the respondents had attended middle level colleges followed by University, post University, Secondary School and others in the order of $25 \%, 12.5 \%, 7.5 \%$ and $2.5 \%$ respectively as illustrated by Table 8 above. This means that the respondents were adequately qualified persons academically and had knowledge of what was being investigated.

\subsubsection{Respondents' Job position in the Organization}

Table 9. Distribution of Respondents'Job position in the Organization.

\begin{tabular}{cllll}
\hline Job position & Frequency & Percent & Cumulative Percent \\
\hline Top Management & 1 & 2.5 & 2.5 \\
Valid Middle Management & 12 & 30.0 & 32.5 \\
Lower Management & 27 & 67.5 & 100.0 \\
Total & 40 & 100.0 & \\
\hline
\end{tabular}

Source: Survey data, 2015

The sample size was 42 employees of KIRIWASCO of which the returned response was 40 . Table 9 above shows that majority of respondents in this study were employed in lower level management $(67.5 \%)$ followed by middle level management and top level management in the order of $30 \%$ and $2.5 \%$ respectively. From the above results, we can conclude that the majority of the respondents in this study were lower and middle level managers and were able to give the necessary information since they know more about the organization's stakeholders, business, and profits among others.

\subsubsection{Work Experience}

The researcher sought to discover how long respondents had worked with KIRIWASCO since the more one stays, the more experience gained and hence more information for the research. The sample size was 42 employees of KIRIWASCO of which the returned response was 40 . The study established the duration of time respondents had worked at KIRIWASCO as presented in Table 10 below.

Table 10. Distribution of Respondents in terms of Work Experience.

\begin{tabular}{lllll}
\hline Work experience & Frequency & Percent & Cumulative Percent \\
\hline \multirow{4}{*}{ Valid } & 1-5 years & 16 & 40.0 & 40.0 \\
& 6-10 years & 19 & 47.5 & 87.5 \\
& $11-15$ years & 4 & 10.0 & 97.5 \\
& 16-20 years & 1 & 2.5 & 100.0 \\
& Total & 40 & 100.0 & \\
\hline
\end{tabular}

Source: Survey data, 2015

From the findings, majority of respondents $(47.5 \%)$ had worked at the company for periods over $6-10$ years, $40 \%$ for periods between $6-10$ years, $10 \%$ between $11-15$ years and $2.5 \%$ for periods between 16 and 20 years as illustrated by Table 10 above. This implies that majority of the respondents were familiar with the running of the organization and especially auditing practices in use.

\subsection{Auditor's Independence}

The following were the findings on the Auditor's Independence.

Table 11. Statements relating to Auditor's Independence.

\begin{tabular}{|c|c|c|c|c|c|c|c|c|}
\hline \multirow[b]{2}{*}{ Factor } & \multirow[b]{2}{*}{ Response } & \multicolumn{5}{|l|}{ Rating } & \multirow[b]{2}{*}{ Mean } & \multirow{2}{*}{$\begin{array}{l}\text { Std. } \\
\text { deviation }\end{array}$} \\
\hline & & $\begin{array}{l}\text { Strongly } \\
\text { agree }\end{array}$ & Agree & Neutral & Disagree & $\begin{array}{l}\text { Strongly } \\
\text { disagree }\end{array}$ & & \\
\hline \multirow{2}{*}{$\begin{array}{l}\text { In your opinion, how do you agree tenure of auditor } \\
\text { influences auditor's independence at KIRIWASCO? }\end{array}$} & $\mathrm{F}$ & 17 & 13 & 10 & - & - & \multirow{2}{*}{1.83} & \multirow{2}{*}{0.813} \\
\hline & $\%$ & 42.5 & 32.5 & 25.0 & - & - & & \\
\hline \multirow{2}{*}{$\begin{array}{l}\text { In your opinion, how do you agree audit firm size influence } \\
\text { auditor's independence at KIRIWASCO? }\end{array}$} & $\mathrm{F}$ & 9 & 14 & 12 & 5 & - & \multirow{2}{*}{2.33} & \multirow{2}{*}{0.971} \\
\hline & $\%$ & 22.5 & 35.0 & 30.0 & 12.5 & & & \\
\hline \multirow{2}{*}{$\begin{array}{l}\text { In your opinion, how do you agree that a degree of } \\
\text { competition influences auditor's independence at } \\
\text { KIRIWASCO? }\end{array}$} & $\mathrm{F}$ & 3 & 12 & 14 & 10 & 1 & \multirow[b]{2}{*}{2.79} & \multirow[b]{2}{*}{0.923} \\
\hline & $\%$ & 7.5 & 30.0 & 35.0 & 25.0 & 2.5 & & \\
\hline \multirow{2}{*}{$\begin{array}{l}\text { In your opinion, how do you agree non audit fees services } \\
\text { influence auditor's independence at KIRIWASCO? }\end{array}$} & $\mathrm{F}$ & 10 & 15 & 8 & 6 & 1 & \multirow{2}{*}{2.26} & \multirow{2}{*}{1.019} \\
\hline & $\%$ & 25.0 & 37.5 & 20.0 & 15.0 & 2.5 & & \\
\hline
\end{tabular}

Source: Survey data, 2015

The study sought to determine the level at which respondents agreed or disagreed with the above statements relating to auditor's independence and financial performance of KIRIWASCO. From the findings in Table 11 above, the 
study established that majority of the respondents strongly agreed that tenure of the auditor influences auditor's independence as shown by a mean of 1.83 , and that audit firm size influences auditor's independence as shown by a mean of 2.33. Majority of respondents also agreed that a degree of competition in procuring audit services influences auditor's independence as shown by a mean of 2.79 and that non audit fees services influence auditor's independence at
KIRIWASCO as shown by a mean of 2.26. Therefore respondents agreed that auditors' independence creates the basis for objective review of company activities that it influences performance of auditors to a great extent as indicated by these findings. Carcello (2005) found that was a significant relationship between external auditor independence and financial performance.

Management Support to Audit Reports.

Table 12. Statements relating to Management Support to Audit Reports.

\begin{tabular}{|c|c|c|c|c|c|c|c|c|}
\hline \multirow{2}{*}{ Factor } & \multirow{2}{*}{ Response } & \multicolumn{5}{|l|}{ Rating } & \multirow{2}{*}{ Mean } & \multirow{2}{*}{$\begin{array}{l}\text { Std. } \\
\text { deviation }\end{array}$} \\
\hline & & Strongly agree & Agree & Neutral & Disagree & Strongly disagree & & \\
\hline \multirow{2}{*}{ Audit reports are communicated in time } & $\mathrm{F}$ & 15 & 20 & 5 & - & - & \multirow{2}{*}{1.75} & \multirow{2}{*}{0.797} \\
\hline & $\%$ & 37.5 & 50.0 & 12.5 & - & - & & \\
\hline \multirow{2}{*}{$\begin{array}{l}\text { Management is provided with timely, reliable } \\
\text { and relevant information }\end{array}$} & $\mathrm{F}$ & 15 & 15 & 10 & - & - & \multirow{2}{*}{1.88} & \multirow{2}{*}{0.906} \\
\hline & $\%$ & 37.5 & 37.5 & 25 & - & - & & \\
\hline $\begin{array}{l}\text { Senior management respond positively to } \\
\text { internal Audit findings and recommendations }\end{array}$ & $\mathrm{F}$ & - & - & 10 & 30 & - & 3.75 & 0.533 \\
\hline \multirow{2}{*}{$\begin{array}{l}\text { Information is provided to the company's } \\
\text { stakeholders on request }\end{array}$} & $\mathrm{F}$ & - & - & 25 & 5 & 10 & \multirow{2}{*}{3.63} & \multirow{2}{*}{0.742} \\
\hline & $\%$ & - & - & 62.5 & 12.5 & 25.0 & & \\
\hline
\end{tabular}

Source: Survey data, 2015

The study sought to determine the level at which respondents agreed or disagreed with the above statements relating to management support to audit reports and financial performance of KIRIWASCO. From the findings shown on Table 12 above the study established that majority of the respondents strongly agreed that audit reports were communicated on time as shown by a mean of 1.75 . Regarding audit reporting, majority of the respondents agreed that management was provided with timely, reliable and relevant information as shown by a mean of 1.88; however, most respondents agreed that senior management did not respond positively to internal audit findings and recommendations as shown by a mean of 3.75. Regarding information and communication to stakeholders, majority of the respondents agreed that they were not sure whereas $37.5 \%$ of the respondents said that company information was not communicated to stakeholders as shown by a mean of 3.63. Therefore respondents agreed that management support significantly influenced audit effectiveness in KIRIWASCO.

\subsection{Financial Performance}

The following is the findings on financial performance Profit Realized and Employees Satisfaction

The respondents were asked to provide their views profit realized and employees' satisfaction, below was the results.

Table 13. Statements relating to Profits realized and Employees Satisfaction.

\begin{tabular}{|c|c|c|c|c|c|c|c|c|}
\hline \multirow{2}{*}{ Factor } & \multirow{2}{*}{ Response } & \multicolumn{5}{|l|}{ Rating } & \multirow{2}{*}{ Mean } & \multirow{2}{*}{$\begin{array}{l}\text { Std. } \\
\text { deviation }\end{array}$} \\
\hline & & Strongly agree & Agree & Neutral & Disagree & Strongly disagree & & \\
\hline \multirow{2}{*}{$\begin{array}{l}\text { The company is making enough } \\
\text { profits }\end{array}$} & $\mathrm{F}$ & 6 & 2 & - & 27 & 5 & \multirow[t]{2}{*}{3.77} & \multirow[t]{2}{*}{0.427} \\
\hline & $\%$ & 15.0 & 5.0 & - & 67.5 & 12.5 & & \\
\hline \multirow{2}{*}{$\begin{array}{l}\text { Employees are satisfied with the } \\
\text { company's financial performance }\end{array}$} & $\mathrm{F}$ & 2 & 6 & 17 & 12 & 3 & \multirow[t]{2}{*}{3.59} & \multirow[t]{2}{*}{0.850} \\
\hline & $\%$ & 5.0 & 15.0 & 42.5 & 30.0 & 7.5 & & \\
\hline
\end{tabular}

Source: Survey data, 2015

The study sought to determine the level at which respondents agreed or disagreed with the above statements relating to profitability and whether employees were satisfied with the current performance of KIRIWASCO. From the findings shown on Table 13 above majority of the respondents disagreed that the company was making enough profits as shown by a mean of 3.77 and majority of employees were not satisfied with the company's performance as shown by a mean of 3.59 .

Following these results, it was established that majority of the respondents were not agreeable that the company was making enough profits and majority of employees were dissatisfied with the company's performance. Falaye and Trahan (2007) support that employee satisfaction results in higher productivity and profitability, which creates value for the shareholders. Filbeck and Preece (2003) find positive market reaction and better long term market performance for companies with satisfied employees.

\subsection{Moderating Effect}

The moderating effect is the hierarchical regression analysis to determine change in coefficient of correlation $(R)$, change 
in coefficient of determination $\left(R^{2}\right)$ and significance effects. This measure shows the increase in variation explained by the addition of the moderating variable. The results of the moderating effect are shown below:

Table 14. Model Summary for moderating Variable.

\begin{tabular}{|c|c|c|c|c|c|c|c|c|c|}
\hline \multirow{2}{*}{ Model } & \multirow{2}{*}{$\mathbf{R}$} & \multirow{2}{*}{ R Square } & \multirow{2}{*}{ Adjusted R Square } & \multirow{2}{*}{$\begin{array}{l}\text { Std. Error of the } \\
\text { Estimate }\end{array}$} & \multicolumn{5}{|l|}{ Change Statistics } \\
\hline & & & & & R Square change & F Change & df1 & df2 & Sig. F Change \\
\hline 1 & $0.773^{\mathrm{a}}$ & 0.598 & 0.305 & 0.901 & 0.626 & 67.368 & 1 & 40 & 0.000 \\
\hline 2 & $0.794^{\mathrm{b}}$ & 0.630 & 0.218 & 0.955 & 0.032 & 0.925 & 1 & 39 & 0.341 \\
\hline
\end{tabular}

Source: Survey data, 2015

Table 14 above provides the change in $R^{2}$ measure which we can use to determine the statistical significance of the moderating variable and subsequently whether management support moderates the effect of auditing on financial performance. As shown in the table $R^{2}$ changes positively by 0.032 from 0.773 to 0.794 . This accounts for $3.2 \%$ change. The F-value for change is 0.925 . From the table the overall change in $R$ and change in $R^{2}$ is more than $1 \%$ and is therefore statistically significant.

\subsection{Hypothesis Testing}

To test the hypothesis the following correlation and regression analysis were undertaken. The results was as indicated below

Table 15. Correlation analysis.

\begin{tabular}{llc}
\hline \multirow{3}{*}{ Financial Performance } & \multicolumn{2}{l}{ Auditor's independence $\left(\mathrm{X}_{2}\right)$} \\
& Correlation (R) & $0.422^{* *}$ \\
& Sig. (2-tailed) & 0.007 \\
\hline
\end{tabular}

Source: Survey data, 2015
A null hypothesis that auditor's independence has no significant impact on the financial performance of KIRIWASCO was formulated with a view to assessing whether or not auditor's independence influences financial performance in the water company. The result for the test of hypothesis demonstrates a significant positive relationship between auditor's independence and financial performance. $(\mathrm{R}=0.422$, Sig. 2 -tailed ( $\mathrm{p}$ value $=0.007)$. These findings, as indicated in table 15 above, can be generalized given that the significance level p-value $<0.05$, while the correlation coefficient was 0.422 . Therefore, these produced the evidence of rejecting the null hypothesis that auditor's independence has no significant impact on the financial performance of KIRIWASCO. We therefore reject the null hypothesis, which is $\mathrm{H}_{01}$ : Auditor's independence has no significant impact on financial performance of KIRIWASCO and we accept $\mathrm{H}_{1}$ since auditor's independence significantly contributes to the model and is supported by the empirical data obtained.

Table 16. Regression Analysis.

\begin{tabular}{|c|c|c|c|c|c|}
\hline \multirow{2}{*}{\multicolumn{2}{|c|}{ Model }} & \multicolumn{2}{|c|}{ Unstandardized Coefficients } & \multirow{2}{*}{ t-statistic } & \multirow{2}{*}{ Sig. (p-value) } \\
\hline & & B & Std. Error & & \\
\hline \multirow{4}{*}{1} & Intercept (Constant) & 2.563 & 0.950 & 2.697 & 0.013 \\
\hline & Auditor's independence & 0.2967 & 0.335 & 0.497 & 0.005 \\
\hline & Internal Audit function & 0.2413 & 0.298 & 1.050 & 0.167 \\
\hline & Audit Committee & 0.1207 & 0.149 & 0.404 & 0.033 \\
\hline
\end{tabular}

Source: Survey data (2015)

From the above regression model, it was found that financial performance in KIRIWASCO would be at 2.563 holding corporate governance, auditors' independence, internal auditing function and audit Committee constant. A unit increase in auditors' independence would lead to increase in financial performance in KIRIWASCO by factor of 0.2967 with a P Value of 0.005 .

\subsection{Testing of the Study Model}

The researcher sought to determine goodness of fit of the study model. The following ANOVA test was undertaken.

Table 17. ANOVA Test.

\begin{tabular}{|c|c|c|c|c|c|c|}
\hline \multicolumn{7}{|c|}{ ANOVA $^{a}$} \\
\hline & & Sum of Squares & df & Mean Square & $\mathbf{F}$ & Sig. \\
\hline \multirow{3}{*}{1} & Regression & 26.516 & 16 & 1.657 & \multirow[t]{3}{*}{2.043} & \multirow[t]{3}{*}{$0.040^{b}$} \\
\hline & Residual & 17.842 & 22 & .811 & & \\
\hline & Total & 44.359 & 38 & & & \\
\hline
\end{tabular}

Source: Survey data, 2015 
The regression model used was significant with the $\mathrm{F}$ statistic of 2.043 was significant at $p=0.040$ as shown in table 17 above which was less than the acceptable significance level of 0.05 . This means that the independent variables not only have positive influence on financial performance but also their influence is significant. Based on this outcome, the prediction of the outcome of the study using this model was acceptable i.e. determination of financial performance (return on investment) by the independent variables namely the auditor's independence.

Summary of the Study Model

From the Regression $\mathrm{R}^{2}$ test and ANOVA test, all the variables were found to be significance. The model for one variable indicated above would $\mathrm{Y}=2.563+0.2967 \mathrm{X}_{2}$

Where $\mathrm{Y}=$ Financial performance

$2.563=$ Constant, and 0.2967 is the Regression Coefficients, $\mathrm{X}_{1}=$ Auditors independence。

\section{Summary, Conclusion and Recommendations}

This chapter gives a summary of the findings outlined in chapter four, the conclusion and recommendations of the study on the effect of auditing on financial performance in Kirinyaga Water and Sanitation Company. Included is the conclusion relating to findings, recommendations and areas of future research.

\subsection{Summary of Findings}

The rationale for this research project was to determine empirically the effect of auditor's independence and their centrality on financial performance in Kirinyaga Water and Sanitation Company ltd.

Effect of Auditor's Independence on Financial Performance

The researcher sought to determine the impact of auditor's independence on financial performance. The opinions of respondents in this regard presented in Table 4.19 indicate that there is a positive effect of auditor's independence on financial performance (regression coefficient $=0.2967 ; p=0.005$ ). This study found that auditor's independence positively affects financial performance with over $29.67 \%$ of the variance explained. These results confirm the relative importance of auditor's independence on financial performance. As discussed in the literature review, auditors are expected to be objective at all times in the course of their duties. An auditing function needs to be free from interference in determining the scope of its work, performing its duties and communicating its results. The independence of an auditor guarantees objectivity and imposes trust and confidence in the users of the financial statements.

\subsection{Conclusions}

The results of the study reveal that there is a positive relationship between financial performance success the predictor variable auditor's independence. Because of the emergent relationship between the predictor variable and financial performance, the study concluded that auditor's independence as moderated by management support to auditing is a catalysts of financial performance without which auditing may not add value to the operations of the organization.

\subsection{Policy Recommendations}

In view of the conclusions reached, the study recommends that Kirinyaga Water and Sanitation Company should maintain and enhance the existing internal control environment and audit assurance services since the study revealed a positive significant effect on financial performance by the attributes. In addition, the improvement of internal control activities, procedures and policies should be regularly revised at least annually.

\section{Appendix}

Questionnaire

This questionnaire is on the effects of auditing on financial performance. Please kindly respond to the questions by ticking in the boxes or writing your response in the space provided. I request you to respond as fairly and truthfully as possible. All information given will be treated with almost confidentiality.

Section A: Biodata

1. What is your Gender? (Tick as applicable)

a) Female

b) Male

2. What is your Marital Status?

a) Single

b) Married

c) Widow/ widower

d) Separated

e) Divorced

3. Which is your Age group?
a) $18-30$
b) $31-40$
c) $41-50$
d) $51-60$
e) Over 60

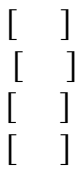

4. What is your highest Education level achieved?

a) Secondary school

b) Middle level college

c) University

d) Post-university

e) Other (specify)

5. What Management Level do you hold in the organization?

a) Top Management

b) Middle Management

c) Lower Management 
6 . How long have you been in that position?
a) 1-5 years
b) 6-10 years
c) $11-15$ years
d) 16-20 years
e) Above 20 years

Section B: Effect of Auditing on Financial Performance

(i) Corporate Governance

To what extent do you think the following factors have effect on financial performance of Kirinyaga Water and Sanitation Company in Kirinyaga County?

Table A1. Corporate Governance.

Key: $1=$ To very great extent, $2=$ To great extent, $3=$ To moderate extent, $4=$ To low extent, $5=$ Not at all

\begin{tabular}{ll|llll}
\hline Factor & Rating & & & \\
\hline Transparency and Disclosure & 1 & 2 & 3 & 4 & 5 \\
Accountability & 1 & 2 & 3 & 4 & 5 \\
Risk Management Measures & 1 & 2 & 3 & 4 & 5 \\
Management Integrity and Ethical Values & 1 & 2 & 3 & 4 & 5 \\
\hline
\end{tabular}

\section{(ii) Audit Independence}

In your opinion, how do you agree the following factors influence audit independence on financial performance of Water and Sanitation Company in Kirinyaga County?

Table A2. Audit Independence.

Key: 1. Strongly agree, 2. Agree, 3. Neutral, 4. Disagree, 5. Strongly disagree

\begin{tabular}{llllll}
\hline Factor & Rating & & & \\
\hline Tenure of Audit & 1 & 2 & 3 & 4 & 5 \\
Audit Firm Size & 1 & 2 & 3 & 4 & 5 \\
Degree of Competition & 1 & 2 & 3 & 4 & 5 \\
Non Audit Fees & 1 & 2 & 3 & 4 & 5 \\
\hline
\end{tabular}

(iii) Management support to Audit Reports

Please respond by ticking in one box per question from strongly agree to strongly disagree

Table A3. Management support to Audit Reports.

Key: 1. Strongly agree, 2. Agree, 3. Neutral, 4. Disagree, 5. Strongly disagree

\begin{tabular}{lllllll}
\hline Factor & Rating & & & \\
\hline $\begin{array}{l}\text { Audit reports are communicated in time } \\
\begin{array}{l}\text { Management is provided with timely, reliable } \\
\text { and relevant information }\end{array}\end{array}$ & 1 & 2 & 3 & 4 & 5 \\
$\begin{array}{l}\text { Senior management respond positively to } \\
\text { internal audit findings and recommendations }\end{array}$ & 1 & 2 & 3 & 4 & 5 \\
$\begin{array}{l}\text { Information is provided to the company's } \\
\text { stakeholders on request }\end{array}$ & 1 & 2 & 3 & 4 & 5 \\
\hline
\end{tabular}

\section{(iv) Financial Performance}

Please respond by ticking in one box per question from strongly agree to strongly disagree

Table A4. Financial Performance.

Key: 1. Strongly agree, 2. Agree, 3. Neutral, 4. Disagree, 5. Strongly disagree

\begin{tabular}{llllll}
\hline Factor & Rating \\
\hline $\begin{array}{l}\text { The company is making enough profits } \\
\begin{array}{l}\text { Employees are satisfied with the } \\
\text { company's financial performance }\end{array}\end{array} 11$ & 2 & 3 & 4 & 5 \\
\hline
\end{tabular}

\section{References}

[1] Adams, R. B, \& Mehran, H. (2005). Corporate Performance, Board Structure and its determinants in the Banking Industry in EFA 2005 Moscow meetings.

[2] Adeniji, A. A. (2004) Auditing and Investigations, Lagos: El-Toda Ventures ltd.

[3] Akinbuli, S. F. (2010). The effect of audit expectation gap on the work of auditors, the profession and users of financial information, Niger Accountant.

[4] Aldamen H. Duncan K. Kelly S. McNamara R. and Nagel S. (2012). Audit Committee characteristics and firm performance during the global financial crisis, Accounting and Finance.

[5] Barlow, P., Helberg, S., Large, N., and Le Roux, K., (1997). The Business approach of Internal Audit. $2^{\text {nd }}$ edition, S. Africa Bhatti, K., \& Qureshi, T. (2007). Impact of employee participation on job satisfaction, employee commitment and employee productivity. International Review of Business Research Papers.

[6] Borg, W. and Gall, J. (1997). Educational Research. An Introduction. New York: Longman BPP Professional Education

[7] Claessens, J. P. Fan, P. H., Wong, T. J. (2002), A study of the relationship between the independent director system and the operating performance of the business in Taiwan".

[8] CMA, (2002) Guidelines on corporate governance practices by public listed companies in Kenya, CMA, Nairobi.

[9] Demsetz, H., Villalonga, B. (2002), Ownership structure and corporate performance, Journal of Corporate Finance.

[10] DeZoort, F. T. Hermanson, D. R. Archambeault, D. S. Reed, S. A. (2002) Audit Committee Effectiveness: A Synthesis of the Empirical Audit Committee Literature. Journal of Accounting Literature; 2002; 21, ABI/INFORM Global.

[11] Du Toit, F. (2002) South Africa Trust Laws: Principles and Practice, Butterworths Lexisnexis.

[12] Eklov, G. (2001) Auditability as interface: negotiation and signification of intangibles School of Business Research Reports no. 2001: 09. Stockholm: School of Business, Stockholm University.

[13] Fadzil, F. H. Hasnah, H. Muhamad, J. (2005) Internal Audit practices and Internal Control system. Managerial Auditing Journal.

[14] Faleye O. Trahan E. (2011) Labor-Friendly Corporate Practices: Is What is Good for Employees Good for Shareholders? Journal of Business Ethics, Vol. 101, pp 1-27.

[15] Farouk, M. A., and Hassan, S. U., (2014). Impact of Audit Quality and Financial Performance of Quoted Cement Firms in Nigeria.

[16] Fraenkel, J. R. \& Wallen, N. (2000) How to Design and Evaluate Research in Education. N. E. McGraw-Hill Higher Education.

[17] Freedman, D. A. (2005) Statistical Models: Theory and Practice, Cambridge University Press. 
[18] Hay, S. and Knechel, R. L. V. (2006) Non-Audit Services and Auditor Independence: New Zealand Evidence, Journal of Business Finance and Accounting.

[19] Hayes, R. Dassen, R. Schilder, A. and Wallage, P. (2005) $\left(2^{\text {nd }}\right.$ Ed). Principles Of Auditing: An Introduction to International Standards on Auditing, Prentice Hall.

[20] Ho, S. M. S. (2003) Corporate Governance in China. Kowloom, Hong Kong.

[21] Hudaib, M. (2003) Understanding external auditor independence in Saudi Arabia: perceptions of selected groups of auditors and users, Colchester.

[22] Kothari, C. R. (2000) Research Methodology: Methods and Techniques $\left(2^{\text {nd }} E d\right)$. New Age Publishers.

[23] Krishnan, J. and Lee, J. E. (2009) Audit Committee Financial Expertise, Litigation Risk, and Corporate Governance, Auditing Sarasota.

[24] La Porta, R. Lopez-De Silanes, F. and Shleifer, A. (2000) 'Investor protection and corporate governance', Journal of Financial Economics, vol. 58.

[25] Louise, M. (2005). The effects of auditor independence on audit quality. Paper presented the Department of Accounting, Bowling Green State University.

[26] Mugenda, O. M. and Mugenda, A. G. (2003) Research Methods: Quantitative and Qualitative Approaches, Nairobi: Acts Press.

[27] Muhamad, Z. and Karbhari, Y. (2006) Auditor Reputation and Auditor Independence in an Emerging Market, retrieved from http://www.papers.ssrn.com.
[28] Myers, P. M., and Ziegenfuss, D. E., (2006) "Audit Committee pre-Enron efforts to increase the effectiveness of corporate governance" Corporate Governance, Vol. 6.

[29] NAO (2000). Co-operation between internal and external Auditors, Good Practice Guide, HM Treasury and National Audit Office, UK.

[30] Ombogo, P. L. (2006). Strategy for access to water and sanitation services in informal settlements: The Kisumu Experience. Paper presented at the "Africities Conference", Nairobi, Kenya.

[31] Pimentel, R. C., Braga, R., \& Casa Nova, S. P. C. (2005). Interaçao entre rentabilidadeeliquidez: um estudo exploratório. Revista de Contabilidade do Mestrado em Ciencias Contabeis da UERJ, Rio de Janeiro.

[32] Quick, R. (2012). EC Green Paper Proposals and Audit Quality. Accounting in Europe.

[33] Salehi, M. (2008) Corporate Governance and Audit Independence: Empirical Evidences from Iran. International Journal of Business and Management.

[34] Sandeep, A. Patel, A. B. \& Lilicare, B. (2002) Measuring transparency and disclosure at firm-level in emerging markets, Lil.

[35] Sarens, G. and Debeelde I. (2004) Contemporary Internal Auditing Practices; New Roles and Influencing Variables. Evidence from extended case studies, working paper series. 